\title{
Koroze a porucha na vozidle jako př́čina dopravní nehody
}

\section{Corrosion and a vehicle failure as a cause of a traffic accident}

\author{
Řehák M. ${ }^{1}$, Drahotský I. ${ }^{2}$ \\ 1 Česká zemědělská univerzita v Praze \\ ${ }^{2}$ Univerzita Pardubice \\ E-mail: nehody.rehak@seznam.cz
}

Článek se zabývá skupinou dopravnich nehod, u kterých byla nebo mohla být přičinou porucha nékterého z dílù vozidla $v$ důsledku korozního napadení. Je popsán současný stav poruch jako príčin dopravních nehod $v$ České republice av zahraničí, dále pak problematika jejich hodnoceni. V príspěvku jsou popsány dvě varianty, kde se analytik dopravnich nehod setká s korozi. Jednak s korozi jako poruchou, která byla přićinou nehodového děje, jednak s korozi jako následným poškozením, které znemožni vyhodnoceni možné poruchy. U obou jmenovaných oblastí jsou uvedeny príklady z reálných dopravních nehod, $k d y v$ prípadě poruchy brzdového systému vozidla, kde prićinou byla koroze, je proveden experiment pro objasnění závislosti tloušt ky stěny potrubi a jejího vnějšího průměru pokrytého korozní zplodinou, tedy zda je možné odhadnout skrze vrstvy koroznich produktů na povrchu potrubi bezpečnou tloušt'ku stěn.

\section{ÚVOD}

V drtivé většině případů se praxe soudních znalců dopravních nehod odvíjí $\mathrm{v}$ rovině nehod, kde jejich příčinou byl lidský faktor. Lze se však setkat i s nehodami, kde př́činou byla porucha, kterou lze definovat jako jev spočívající $\mathrm{v}$ ukončení schopnosti objektu plnit požadovanou funkci [1]. V takových př́padech znalec nebo přibraný odborník zkoumá i mechanismus poruchy, což je souhrn fyzikálních, chemických a dalších procesů. Ve znalecké analýze je pak porucha přiřazována k časové ose vzniku a průběhu nehodového děje. Na poruchu, která byla nebo mohla být př́činou nehodového děje, je pak nahlíženo $\mathrm{z}$ různých úhlů. Ve vztahu $\mathrm{k}$ analýze nehodového děje se bude jednat především o skupiny vozidla, jako jsou nápravy, řízení, brzdy a kola. Poté je nutno analyzovat, zda byla porucha součásti zapříčiněna prasklinou, lomem, deformací, nebo primárně selháním v důsledku korozního poškození. Různé poruchy pak mohou způsobit různé přćčiny ztráty funkce skupiny
This article is dealing with such a group of traffic accidents in which a failure at vehicle could have been or actually was caused by some defect of a car part caused by corrosion. Up-to-date situation in terms of failures as causes of traffic accidents both in the Czech republic and abroad is described here and furthermore, the issue related to their assessment. In this contribution, there are described two possible situations which a traffic accident analyst can be confronted with. Firstly, it is corrosion as a failure that was the reason for an accident or secondly, it can be dealt with corrosion as an after-demage that makes assessing a possible failure unable. For both given areas, the examples of traffic accidents, that really happened, are given here - an experiment has been carried out in case of a brake system failure in which the cause was corrosion and this experiment should lead to explanation if there is a relation between the width of a pipe side and its outer diameter covered by corrosion that means if it was possible to foretell a safe width of a pipe side through assessing the corrosion covers on the surface of a pipe.

vozidla jako např́iklad zablokování kola, ztrátu funkce ř́zení, změnu geometrie kol apod.

Kvalita a možnosti technické analýzy dopravních nehod velmi úzce souvisí s kvalitou sběru a zajišt’ování technických podkladů [2]. Na objektivní a z technického hlediska správný výsledek analýzy dopravní nehody má vliv nejenom vhodně zvolená analýza a její kvalitativní stránka věci, ale i tzv. vstupní údaje, tedy technické podklady. Pro analýzu dopravní nehody jsou technické podklady zcela zásadní. Lze je hodnotit jako dostatečné, podmíněně dostatečné a nedostatečné. Nedostatečné podklady neumožňují korektní analýzu nehody. Toto téma prŕíspěvku bylo zvoleno především $\mathrm{z}$ důvodu nesjednocených postupo̊ pro analýzu dopravních nehod, při kterých je zapotřebí hodnocení poruch jako technických příčin, a také z důvodu upozornění vlivu času na vypovídající hodnotu odebraného vzorku poškozené části automobilu - vazba hodnotitelnosti vzorků v závislosti na čase. 


\section{KOROZE A PORUCHA VE ZNALECKÉ PRAXI}

\section{Porucha jako příčina nehody}

Jak již bylo popsáno v úvodu, dopravní nehody, u nichž byla porucha príičinou, nejsou tak časté, avšak vyskytují se. Nelze je tedy přehlížet a u nezdokumentovaných nehod je nelze zcela vyloučit. V České republice dle statistických podkladů Policie ČR nečiní technická závada jako příčina ani jedno procento, v období let 2005 až 2012 v průměru $0,6 \%$ [3]. Tento statistický údaj je zatížen značnou chybou ze strany Policie České republiky, a to z toho důvodu, že jsou zaznamenány pouze technické příčiny, o kterých se policisté domnívali na místě dopravní nehody krátce po jejím vzniku. Tyto statistické údaje již nejsou poté korigovány následným znaleckým zkoumáním nebo rozhodnutím správního orgánu či skupinou vyšetřování Policie ČR. Chybí zde tedy zpětná korekce. Svou nezanedbatelnou roli zde hraje i ta skutečnost, že o určité části dopravních nehod není policie vůbec informována. Od 1. 7. 2006 je v platnosti limit povinnosti hlášení nehody policii se škodou 50000 Kč a vyšší, od 1. 1.2009 pak limit 100000 Kč. Díky těmto limitům jsou patrné značné poklesy $\mathrm{v}$ počtech registrovaných dopravních nehod (Obr. 1). Zatímco v roce 2005 před zavedením prvního limitu byla v ČR policií registrována dopravní nehoda $\mathrm{v}$ průměru každých 2,6 min., po zavedení druhého limitu byla např. v roce 2012 dopravní nehoda až každých 6,5 min.

Obdobná situace jako v ČR je i ve Slovenské republice, kde se podíl dopravních nehod s technickou př́činou pohybuje $\mathrm{v}$ rozpětí 0,3 až $0,4 \% \mathrm{z}$ celkového počtu dopravních nehod [4]. O proti tomu ve Spolkové republice Německo se již v odborných kruzích zcela otevřeně hovoří o nízké vypovídací schopnosti statistických údajů tamních úřadů, kde se podle úředních statistik porucha nebo nedostatečná údržba vozidla

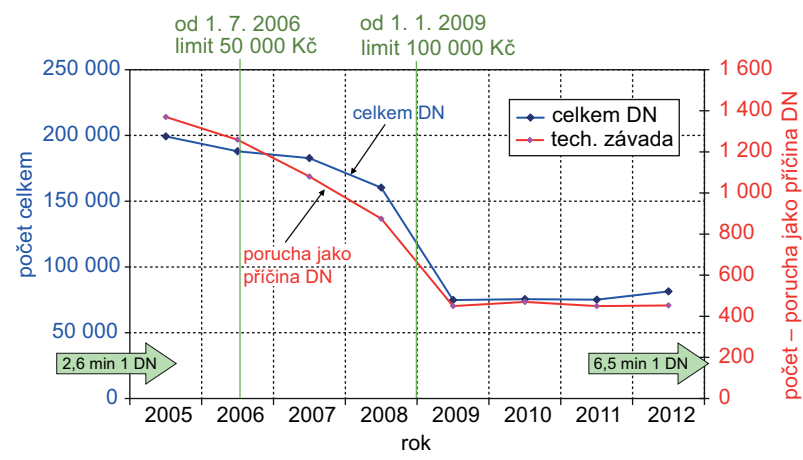

Obr. 1. Celkový počet dopravních nehod v ČR a počet nehod s poruchou jako príčinou [3]

Fig. 1. The total number of road accidents in the Czech republic and the number of road accidents with a failure as the cause of an accident jako př́čina dopravní nehody uvádí pouze v méně než v $1 \%$ př́padů $[5,6]$. Dle nejnovějších statistických údajů z období let 2010 až 2013 tvoří v Německu z celkového počtu policií registrovaných dopravních nehod technické př́činy zhruba stejný podíl jako v České republice. I to lze považovat za poměrně vysoký počet, vezme-li se v potaz, že $\mathrm{z}$ pohledu statistiky dochází $\mathrm{v}$ Německu v průměru každých 14 sekund k nějaké dopravní nehodě [5]. Dle Dr. Priestera [5] by se např. pro situaci v Německu dalo s opatrným hodnocením vycházet ze stínových číselných údajů, které výrazně převyšují oficiální statistiky, takže skutečný podíl poruch na nehodovosti by mohl být v rozmezí cca 3 až $5 \%$.

Pravděpodobně vzhledem $\mathrm{k}$ prezentovanému nízkému podílu poruch jako príčin dopravních nehod je tento problém částečně přehlížen a podceňován. Znalci se $\mathrm{k}$ poškozeným vozidlům a jeho poškozeným částem dostanou často pozdě, někdy vůbec. Automaticky se pak předpokládá, že přičinou nehodového děje byl lidský faktor a možnost poruchy jako pŕíčiny není ani připuštěna. Dostanou-li se znalci k poškozeným částem vozidel $\mathrm{s}$ odstupem času, je vzhledem $\mathrm{k}$ následnému poškození, např́íklad koroznímu napadení, prakticky znemožněno jak relevantní posouzení možné poruchy jako př́čciny nehody, tak i posouzení časového sledu poruchy.

\section{Koroze a porucha}

Pro soudního znalce $\mathrm{v}$ oborech dopravních nehod a posuzování technického stavu koroze naskýtá dvě roviny problému - jednak korozní poškození jako porucha, která byla příčinou dopravní nehody, zadruhé pak korozní napadení jako následné poškození vzorku, např. následné korozní poškození lomu, čímž se zne-možňuje vyhodnocení lomové plochy.

\section{Koroze jako následné poškození}

Není-li krátce po dopravní nehodě ošetřen poškozený díl vozidla - vzorek, u kterého se naskýtá podezření, že byl nebo mohl být příčinou nehodového děje, nastává ve znalecké praxi závažný problém. Vozidla a jejich poškozené části nejsou zpravidla uskladněny $\mathrm{v}$ suchém prostředí, a tak bývají hlavně jejich lomové a funkční plochy napadány korozí. Takto korozí napadené součásti značně ztěžují, nezřídka i znemožňují korektní analýzu, jelikož pak není v silách analytika silničních nehod vyhodnotit lomovou nebo funkční plochu součásti napadené korozí. Také v drtivé většině případů nelze již jednoznačně říci, zda se na posuzované ploše korozní poškození nacházelo již před dopravní nehodou či nikoli. S takovými případy se lze setkat např́klad u lomů vinutých pružin, čepů, brzdových kotoučů nebo u dílů hydraulických systémů brzd, jako např. u pístů brzdičů (Obr. 2). 


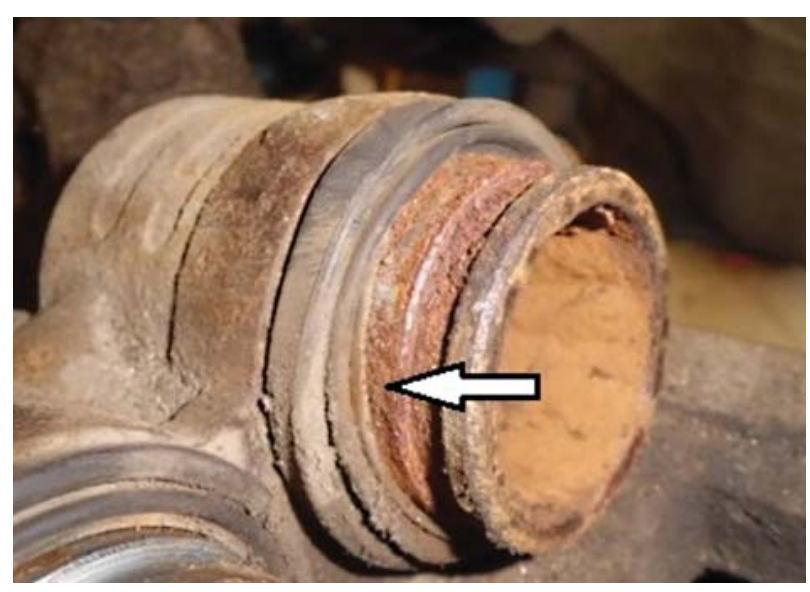

Obr. 2. Korozní poškození dílů brzd

Fig. 2. Corrosion damage of the brake parts

\section{Koroze jako přičina poruchy}

S korozí jako příčinou poruchy se lze v současnosti setkat poměrně často, a to i přes obnovu a omlazování vozového parku. $\mathrm{V}$ takových př́ípadech bývá velmi obtížné rozpoznat poruchu jako př́činu $\mathrm{z}$ důvodů korozního poškození i tehdy, je-li provedena prohlídka poškozeného automobilu krátce po dopravní nehodě. Při prohlídce vozidla po dopravní nehodě (technickém šetření) je zapotřebí zvýšené opatrnosti a pozornosti. Nutnost zvýšené pozornosti lze demonstrovat např́klad šetřením příčiny dopravní nehody osobního vozidla v Německu, kde došlo při nehodovém ději $\mathrm{k}$ převrácení automobilu [7]. Nejprve bylo na místě policií označeno za příčinu nehodového děje chybné jednání řidiče. Avšak soudní znalec při prohlídce vozidla zjistil, že zlomený brzdový kotouč, zapříčený do brzdového třmenu, způsobil zablokování kola, což vedlo k rotaci vozidla a jeho převrácení. Prvotně se však zlomení kotouče přisuzovalo důsledkům rotace vozidla, jelikož obě lomové plochy onoho brzdového kotouče vypadaly velmi podobně, např́íklad jako na Obr. 3. Až bližším pohledem na lomové plochy brzdového kotouče vyrobeného $\mathrm{Z}$ litiny bylo patrné, že se jedná o dvě barevně mírně odlišné plochy. Obě lomové plochy byly za pomoci mikroskopu prozkoumány. Tak bylo následně zjištěno, že u nepatrně světlejší lomové plochy se jedná o čerstvý statický lom. V případě druhé plochy bylo konstatováno, že se zde nachází značně korozně napadená oblast a s tím související korozí zapříčiněné uvolnění struktury. Při následné analýze se pak vycházelo $\mathrm{z}$ toho, že př́íčina zlomení litinového kotouče má základ v mikrotrhlině, a tím $\mathrm{v}$ indukovaném korozním poškození brzdového kotouče. Dále se předpokládalo, že tato mikrotrhlina se mohla při zabrzdění náhle rozšiřrit, čímž se brzdový kotouč nejdříve na zeslabeném místě dále trhal a bezprostředně potom se zlomil v místě, které s ním hraničilo. Potud bylo zlomení brzdového kotouče př́čcinou dopravní nehody. Může existovat mnoho různých př́ičin pro vznik mikrotrhlin, a ne vždy je lze zpětně určit. Zpravidla jsou mikrotrhliny tepelného nebo termomechanického původu a jen málokdy jsou zapříčiněné chybou materiálu. Taková chyba nebyla konstatována ani u tohoto prrípadu. Nebýt důslednosti znalce při technickém šetření, tak by nebyla tato porucha jako příčina dopravní nehody rozpoznána. Dotyčný znalec si všiml, že lomové plochy nejsou naprosto shodné, i když tak na první pohled vypadaly. Po několika dnech nebo týdnech by se na nic nepřišlo, jelikož vzhled obou lomových ploch by byl patrně podobný.

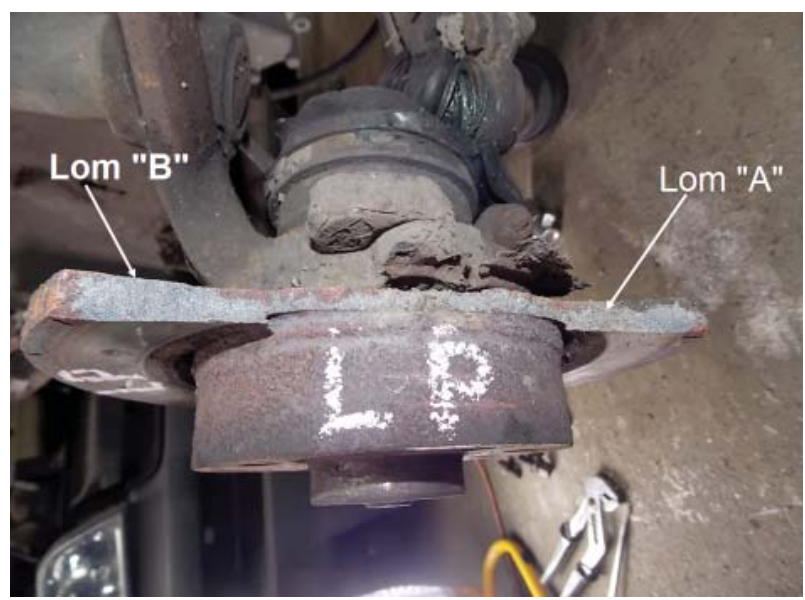

Obr. 3. Dvě barevně velmi mírně odlišné plochy lomu brzdového kotouče

Fig. 3. Two refractive surfaces of a brake disc slightly different in color

Obdobným př́kladem, kde porucha korozně poškozeného dílu vozidla byla nebo mohla být př́ičinou nehodového děje s tragickými následky, je dopravní nehoda staršího vozidla, u kterého řidič v levotočivé zatáčce nebyl pravděpodobně vlivem vyšší rychlosti schopen kopírovat poloměr zatáčky. Došlo k vyjetí automobilu do pŕíkopu mimo komunikaci, $\mathrm{k}$ jeho rotaci a následně $\mathrm{k}$ nárazu do stromu a $\mathrm{k}$ usmrcení řidiče. Již při prvotním ohledání vozidla přivolaným znalcem bylo zjištěno, že jeho brzdový systém je porušen, brzdový pedál se po sešlápnutí propadal, a ze třech brzdových trubiček zadních kol vytékala brzdová kapalina (Obr. 4).

Při důkladném technickém šetření pak bylo zjištěno, že potrubí zadních brzd vyrobené ze speciálních kovových slitin bylo velmi korozně poškozeno (Obr. 4-11). Korozní produkty se nacházely na celém povrchu potrubí. Zkorodované brzdové potrubí bylo při ohledání porušeno destrukcí na třech místech. $\mathrm{Na}$ jednom místě bylo nutno připustit variantu, že $\mathrm{k}$ destrukci značně korozně napadeného potrubí došlo až $\mathrm{v}$ důsledku deformace karosérie při střetu. Ve druhém a třetím př́padě pak bylo prokázáno, že únik brzdové kapaliny z potrubí předcházel nehodovému 
ději. V těchto případech bylo zjištěno, že brzdové potrubí bylo korozním poškozením narušeno $\mathrm{v}$ části průřezu materiálu, což znamená, že na brzdovém systému vozidla docházelo k úniku brzdové kapaliny již před nehodovým dějem. V kritické situaci těsně před střetem, kdy řidič mohl prudce sešlápnout brzdový pedál, mohl se „propadnout“ a nemuselo dojít k vyvození potřebného brzdného účinku. Tak jako $\mathrm{v}$ předchozím uvedeném př́padě, i zde byla porucha odhalena pouze na základě včasné prohlídky vozidla.

Pro další znaleckou analýzu muselo být potrubí z vozidla demontováno, důkladně zdokumentováno (Obr. 5, 6), následně pro úplnost natlakováno kapalinou pro zjištění př́ípadného dalšího porušení, což bylo také prokázáno (Obr. 7). Po zdokumentování a otestování brzdového potrubí mohlo být přistoupeno $\mathrm{k}$ odebrání vzorků (Obr. 8) pro další expertízu (Obr. 9, 10).

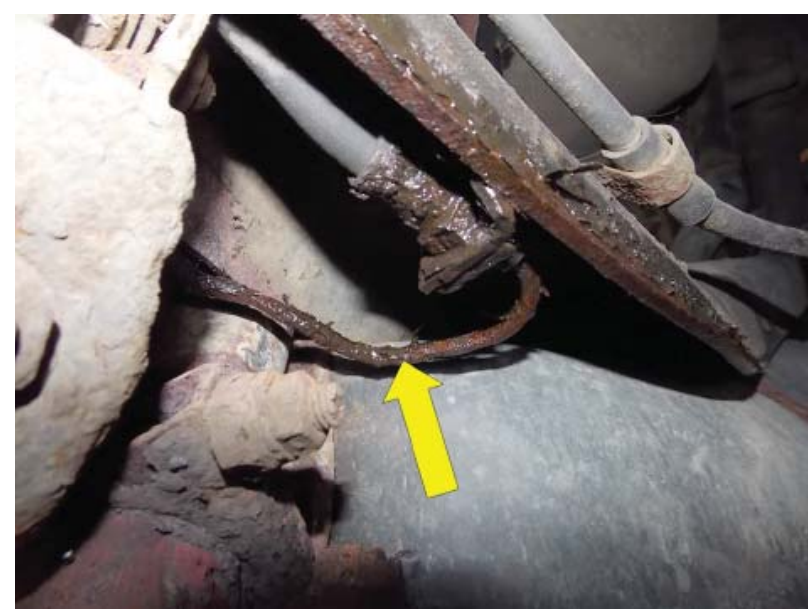

Obr. 4. Únik brzdové kapaliny z korozně poškozené brzdové trubky

Fig. 4. Brake fluid leaking out of a break pipe damaged by corrosion

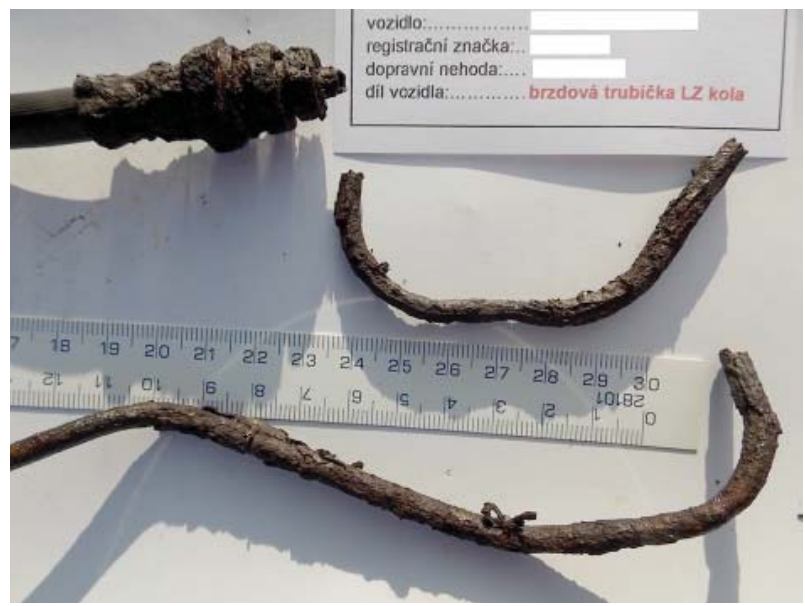

Obr. 5. Korozní poškození brzdového potrubí - celkový pohled

Fig. 5. Brake pipes damaged by corrosion - overall view
Při této následné expertíze odebraných vzorků pak bylo např́klad zjištěno, že na vzorku z brzdové trubičky u omezovače brzdného účinku, kde byl po jejím natlakování zpozorován další únik kapaliny (Obr. 7), docházelo k úniku již před nehodovým dějem, jelikož byl její průřez korozně poškozen na dvou místech (Obr. 9). Na Obr. 9 je patrné jedno narušení průřezu potrubí více korozně napadeného (Obr. 9 - pozice „A“) a jedno narušení průřezu potrubí méně korozně napadeného (Obr. 9 - pozice „B“). Starší korozní poškození průřezu bylo zjištěno i u trubičky brzdy levého zadního kola (Obr. 10). Na tomto vzorku bylo zjištěno jak narušení průřezu korozním poškozením (Obr. 10 - pozice „,Y“), tak i čerstvé lomové plochy (Obr. 10 - pozice „X“).

Automobil s takto korozně poškozeným brzdovým potrubím úspěšně absolvoval periodickou technickou prohlídku na stanici technické kontroly (STK) sedm

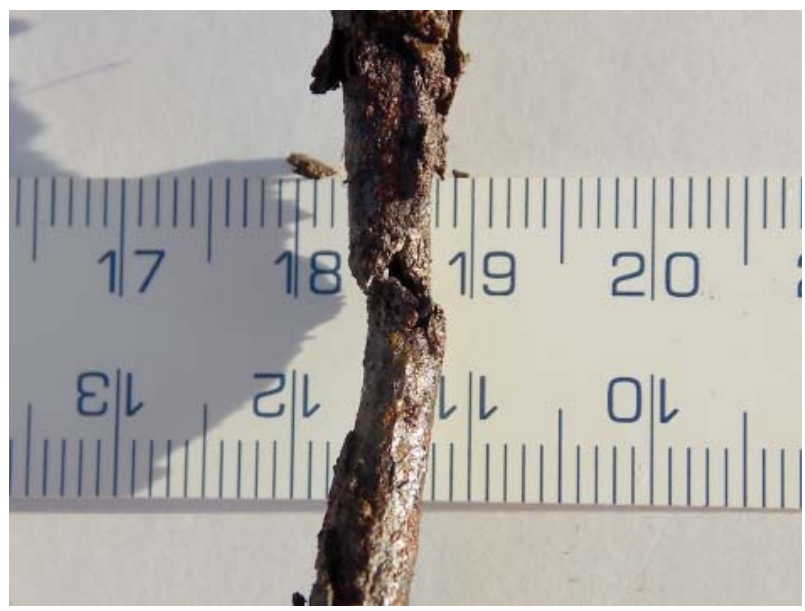

Obr. 6. Korozní poškození brzdového potrubí - detailní pohled

Fig. 6. Brake pipes damaged by corrosion - detailed view

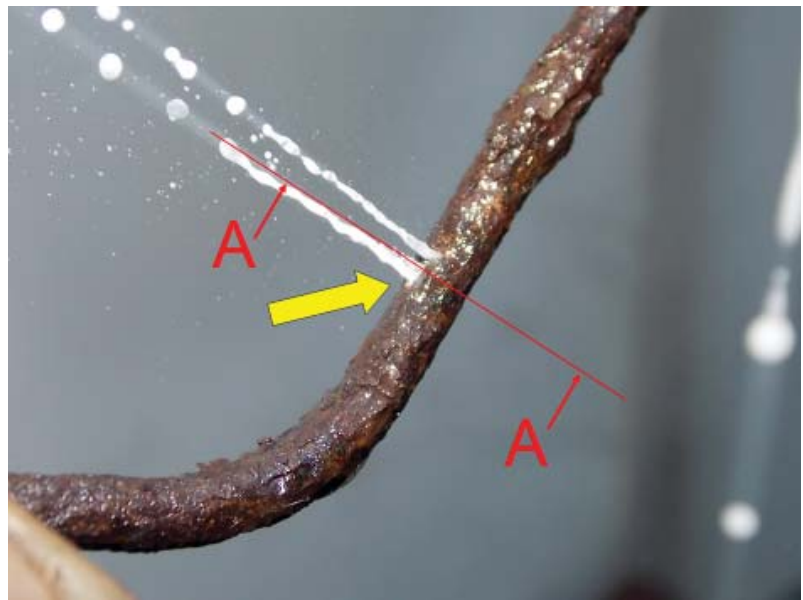

Obr. 7. Zkouška těsnosti potrubí před odběrem vzorků zjištění poruchy

Fig. 7. Pipe leaks test before sampling - finding out a failure 
měsíců před tragickou dopravní nehodou. Toto potrubí nebylo nijak přetřeno ochranným nátěrem a jeho rozsáhlé korozní napadení muselo být patrné i technikovi STK při zmíněné prohlídce. Hodnocení nedostatků zjištěných na vozidlech ve stanici technické kontroly se provádí podle příslušného kontrolního úkonu uvedeného $\mathrm{v}$ příloze č. 7 vyhlášky č. 302/2001 Sb. [8]. v platném znění. Pro kontrolu a hodnocení technického stavu vozidla při technické prohlídce se dle uvedené př́ílohy č. 7 užívají tři stupně závad, které se označují jako A, B a C (A - lehká závada, B - vážná závada, C - nebezpečná závada). $\mathrm{V}$ př́padě pouze lehkých závad, tedy závad stupně A, se osobnímu automobilu uděluje technická způsobilost na dva roky, $\mathrm{v}$ případě zjištění závady $\mathrm{B}$ se pak uděluje způsobilost na jeden měsíc a technická prohlídka se musí opakovat. Je-li zjištěna závada typu C, je vozidlo pro další provoz nezpůsobilé. Přri hodnocení poškozeného nebo korozně poškozeného brzdového potrubí pak technik STK podle uvedené vyhlášky stanoví, zda se jedná o typ závady A, B nebo C, jelikož tato závada může být přiřazena ke všem třem kategoriím závad. Vyhodnocení, o jaký typ závady se jedná, je tedy závislé pouze na subjektivním názoru technika STK.

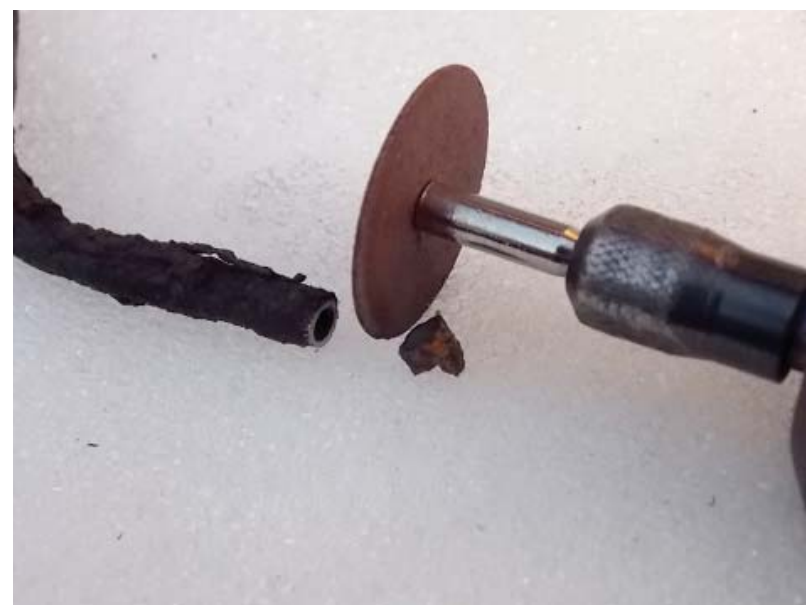

Obr. 8. Odběr vzorků z poškozeného potrubí

Fig. 8. Sampling of pipes damaged by corrosion

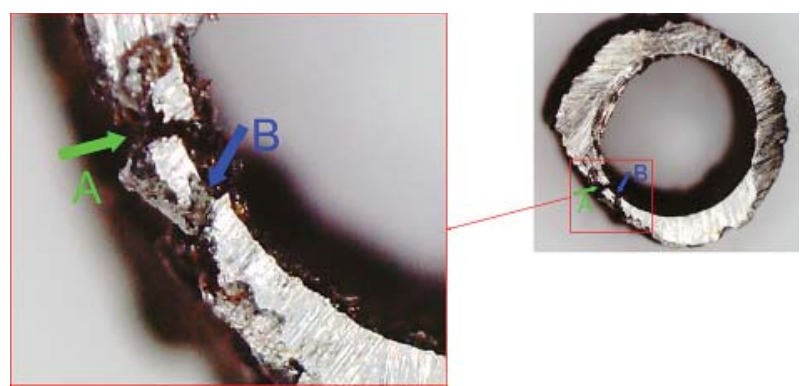

Obr. 9. Detail průniku koroze stěnou brzdové trubky - řez A-A (viz Obr. 7)

Fig. 9. Detail of corrosion penetrating through a brake pipe side- cutting A-A (see the fig.7)
Může dokonce nastat případ, že vozidlu s touto závadou (korozně poškozeným potrubím) bude udělena technická způsobilost.

Tato metodika je tedy pro vyhodnocení poruchy brzdového potrubí velmi benevolentní a do značné míry závislá na lidském faktoru. Technik STK není totiž na první pohled schopen rozpoznat korozní rychlost, a skrze vrstvy korozních produktů na povrchu potrubí nemůže ani odhadnout zbytkovou tloušt'ku stěn. Toto lze demonstrovat na korozněnapadeném ocelovém brzdovém potrubí levé zadní brzdy z výše uvedené nehody, u které bylo zhotoveno celkem osm zkušebních řezů (Obr. 11) a poté $\mathrm{u}$ každého $\mathrm{z}$ nich změřena zbytková tloušt'ka stěny trubky ještě korozně nepoškozené. Před zhotovením řezů byl $\mathrm{v}$ jejich místech změřen vnější maximální průměr potrubí, tedy průměr včetně korozních produktů. Pro názorný př́ílad nemožnosti objektivního odhadu skutečné tloušt'ky stěny stačí porovnat dva řezy, které měly největší vnější průměr včetně korozních produktů. Jednalo se o řez A-A a H-H. Závěrem tohoto jedno-

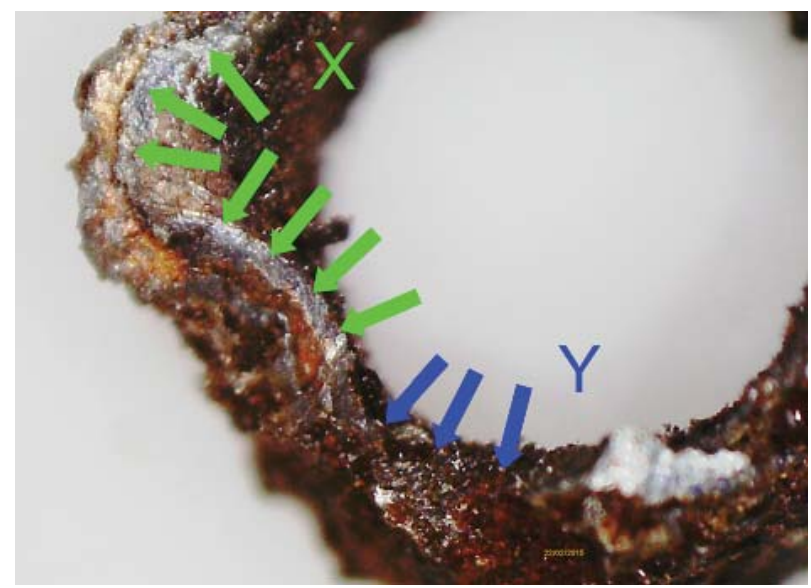

Obr. 10. Korozní poškození brzdové trubky: $\mathrm{X}$ = lomová plocha čerstvého lomu; $Y=$ hloubka průniku koroze stěnou brzdové trubky

Fig. 10. Corrosion damage to a brake pipe. $X=$ fractive surface of a brand new fraction; $Y=$ depth of penetrating of corrosion through a brake pipe side

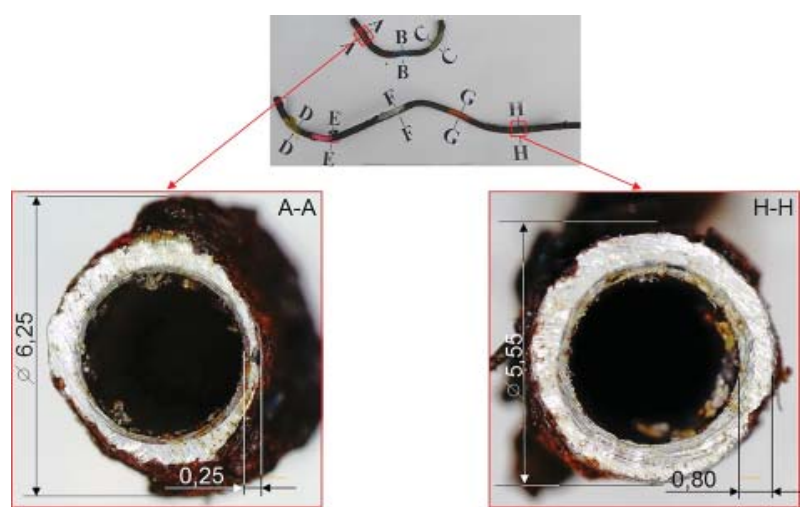

Obr. 11. Tlouštkka stěny a vnější průměr brzdového potrubí Fig. 11. The width of a pipe side and the outer diameter of a brake pipe 
duchého experimentu bylo zjištění, že v řezu „A-A“, kde byl vnější průměr korozně napadeného potrubí $6,25 \mathrm{~mm}$, byla zbytková tloušt'ka stěny již jen $0,25 \mathrm{~mm}$ a v řezu „H-H“, kde byl vnější průměr korozně napadeného potrubí $5,55 \mathrm{~mm}$, byla zbytková tloušt'ka stěny 0,80 mm (Obr. 11). Toto jen potvrzuje výrok, že je-li brzdové potrubí korozně napadeno, nelze již pouhou vizuální prohlídkou odhadnout zbytkovou tloušt'ku stěny, tedy nelze $\mathrm{v}$ takovém případě posoudit míru bezpečnosti. Podrobně je tento experiment uveden v následující kapitole.

\section{EXPERIMENTÁLNÍ ČÁST A VÝSLEDKY}

Pro potřeby znaleckého dokazování byl proveden jednoduchý experiment, částečně popsaný v předchozí kapitole. Cílem bylo objasnění vztahu, tedy závislosti zbytkové tloušt'ky stěny brzdového potrubí automobilu a jejího vnějšího průměru pokrytého korozními produkty. Tedy zda je možné rozpoznat korozní rychlost a zda je možné odhadnout skrze vrstvy korozních produktů na povrchu potrubí zbytkovou tloušt'ku stěn. Na části brzdového potrubí bylo zhotoveno celkem osm zkušebních řezů (Obr. 11) a poté u každého z nich změřena tloušt'ka stěny ještě korozně nepoškozené (Tab. 1). Před zhotovením vzorků byl $\mathrm{v}$ místech řezů změřen vnější maximální průměr potrubí, tedy průměr včetně korozních produktů. Pro porovnání bylo ještě nutné zjistit tyto posuzované hodnoty u nového nepoužitého brzdového potrubí. Nové potrubí ze speciálních kovových slitin má vnější průměr $4,95 \mathrm{~mm}$ a tloušt'ku stěny $0,85 \mathrm{~mm}$

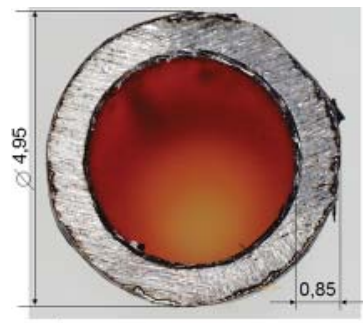

a)

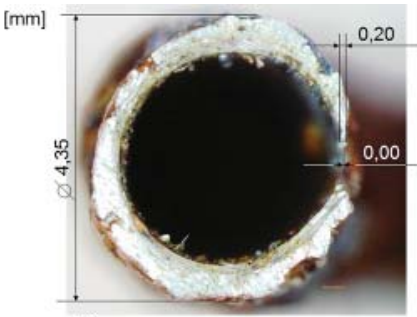

b)
Obr. 12. Řez brzdového potrubí - a) nové potrubí; b) poškozené potrubí v řezu B-B

Fig. 12. A cut of a brake pipe - a) new pipe; b) damaged pipe at cutting $B-B$
(Obr. 12a). Oproti těmto rozměrům nového potrubí byl na zkoumaném vzorku největší rozdíl v řezu B-B, kde mimo nižší hodnotu venkovního průměru byla naměřena i nejnižší zbytková tloušt'ka stěny $0,20 \mathrm{~mm}$, která se navíc při tvorbě vzorku rozpadla a v potrubí vznikl otvor (Obr. 12b).

Ze zjištěných rozměrů korozně poškozeného potrubí (Tab. 1) byl následně vypracován graf (Obr. 13). Je z něj patrné, že je-li zvětšen vnější průměr potrubí vlivem korozních produktů oproti původnímu rozměru, není prakticky možné odhadnout zbytkovou tloušt'ku stěny. Ve dvou řezech, kde byl značně zvětšen vnější průměr potrubí oproti standardu, byla naměřena jak téměř nejnižší zbytková tloušt'ka stěny (Obr. 13 - řez A-A), tak i nejvyšší zbytková tloušt'ka stěny (Obr. 13 řez H-H). Nebyla zde tedy zjištěna závislost zbytkové tloušt'ky stěny na zvětšení vnějšího průměru korozními produkty.

Z grafu je také patrné, že není-li vnější průměr potrubí značně zvětšen korozními produkty, ale zároveň je díky koroznímu poškození tento průměr oproti rozměru nového potrubí zmenšen, je mezi rozměrem vnějšího průměru a rozměrem zbytkové tloušt'ky stěny blíže nespecifikovaná závislost. Tzn., snižuje-li se rozměr vnějšího průměru, snižuje se i zbytková tloušt'ka stěny. Toto lze pozorovat na Obr. 13 od řezu B-B až do řezu G-G, kdy je v tomto intervalu velmi podobný průběh obou křivek.

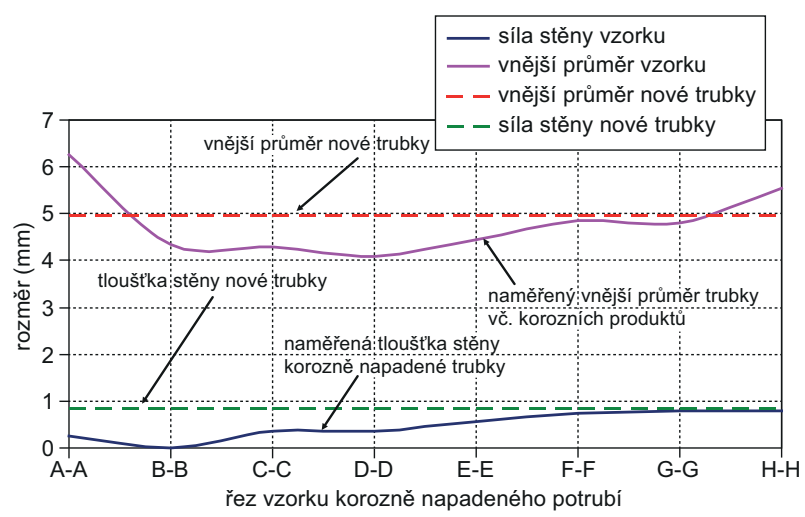

Obr. 13. Graf porovnání rozměrů poškozeného potrubí s novým

Fig. 13. Chart comparing dimensions of the damaged pipes to dimensions of the new ones

Tab. 1. Rozměry korozí poškozené trubky / Proportions of a pipe damaged by corrosion

\begin{tabular}{|c|c|c|c|c|c|c|c|c|}
\hline \multirow{2}{*}{ Zjištěný rozměr } & \multicolumn{9}{|c|}{ ハ̌ez } \\
\cline { 2 - 10 } & $\mathbf{A}-\mathbf{A}$ & $\mathbf{B}-\mathbf{B}$ & $\mathbf{C}-\mathbf{C}$ & $\mathbf{D}-\mathbf{D}$ & $\mathbf{E}-\mathbf{E}$ & $\mathbf{F}-\mathbf{F}$ & $\mathbf{G}-\mathbf{G}$ & H - H \\
\hline Vnější průměr & 6,25 & 4,35 & 4,30 & 4,10 & 4,45 & 4,85 & 4,80 & 5,55 \\
\hline Zbytková tloušt'ka stěny & 0,25 & 0,00 & 0,35 & 0,35 & 0,55 & 0,75 & 0,80 & 0,80 \\
\hline
\end{tabular}




\section{ZÁVĚR}

Z experimentu vyplývá, že je-li vnější průměr brzdového potrubí značně zvětšen korozními produkty, není možné pouze na základě vizuální prohlídky vyslovit závěr o zbytkové tloušt'ce stěny a o bezpečnosti posuzovaného potrubí. Experiment potvrdil nezávislost zbytkové tloušt'ky stěny ocelového potrubí na zvětšení vnějšího průměru korozními produkty. Skrze vrstvy korozních produktů na povrchu potrubí nemůže technik STK odhadnout zbytkovou tloušt'ku stěn, bezpečnost, provozní životnost, tedy ani zbytek technického života potrubí. Vozidlo s korozním poškozením brzdového potrubí by nemělo být provozováno. Z toho vyplývá nutnost změn vyhlášky týkající se hodnocení nedostatků zjištěných na vozidlech ve stanici technické kontroly.

\section{LITERATURA}

1. Mykiska, A. Bezpečnost a spolehlivost technických systémů; České vysoké učení technické v Praze: Praha, 2006.
2. Semela, M. Analýza silničních nehod I., $1^{\text {st }}$ ed.; Vysoké učení technické v Brně, Ústav soudního inženýrství: Brno, 2012.

3. Statistické údaje nehodovosti na území ČR. POLICIE ČR. http://www.policie.cz/clanek/statistika-nehodovosti900835.aspx?q=Y2hudW09NA\%3d\%3d (accessed May 10, 2015).

4. Přehledy základních statistických ukazatelů dopravní nehodovosti. Ministerstvo vnútra Slovenskej republiky. http:// www.minv.sk/?rocenkaSR (accessed May 10, 2015).

5. Priester, J. Technische Mängel - eine gar nicht so seltene Unfallursache?. ZFS Zeitschrift Fuer Schadensrecht 2007, $28(5+6)$.

6. Příčiny dopravních nehod. DESTATIS - Spolkový statistický úřad. //www.destatis.de/EN/FactsFigures/EconomicSectors/ TransportTraffic/TrafficAccidents/TrafficAccidents.html (accessed May 10, 2015).

7. Himbert, G.; Wellner, W. Bremsscheibenbruch als Unfallursache oder Unfallfolge? VKU Verkehrsunfall und Fahrzeugtechnik 2010, 48 (01), 28-31.

8. Vyhláška Ministerstva dopravy a spojů o technických prohlídkách a měření emisí vozidel. Sbirka zákonů České republiky, 302/2001 Sb, Př́loha č.7. 